\title{
Constitution and Composition Chemistry of the Precooked Goatlike Buchada Produced in the State of Paraíba, Brazil
}

\author{
Neube Michel dos Santos ${ }^{1}$, Roberto Germano Costa ${ }^{2}$, Marta Suely Madruga ${ }^{3}$, Ariosvaldo \\ Nunes de Medeiros ${ }^{4}$, Caroline Lima Cavalcante de Albuquerque ${ }^{5}$ and Rita de Cássia \\ Ramos do Egypto Queiroga ${ }^{6 *}$ \\ ${ }^{1}$ Centro Ciências Agrárias; Universidade Federal da Paraíba; João Pessoa - PB - Brasil. ${ }^{2}$ Centro de Formação de \\ Tecnólogos; Universidade Federal da Paraíba; Bananeiras - PB - Brasil. ${ }^{3}$ Centro de Tecnologia; Universidade \\ Federal da Paraíba; João Pessoa - PB - Brasil. ${ }^{4}$ Centro de Ciências Agrárias; Universidade Federal da Paraíba; \\ Areia - PB - Brasil. ${ }^{5}$ PIBIC/CNPq; Universidade Federal da Paraíba; ${ }^{6}$ Centro de Ciências da Saúde; Universidade \\ Federal da Paraíba; rcqueiroga@uol.com.br; João Pessoa - PB - Brasil
}

\begin{abstract}
The objective of the present work was to quantify the constitution and composition chemistry of the precooked goat buchada produced in the state of Paraíba, Brazil. The goat buchada presented considerable yield in relation to the live weight. High protein content was observed in the products analyzed. The lipid content presented high variation as result of the lack of standardization of products produced in the state and no control on parameters such as age, weight and breed of the slaughtered animals was observed. Although no difference $(P<0.05)$ in the lipid content was observed, the highest percentages were observed in samples from Remígio and Barra de Santa Rosa, with 14.52 and $15.90 \%$, respectively, as result of the addition of high amounts of omental and mesenteric fat in the buchada and probably the slaughter of older animals.
\end{abstract}

Key words: "buchada" yield, fat, organs, protein, viscera

\section{INTRODUCTION}

Goat breeding has been currently seen as a relevant economic activity for the Northeastern region of Brazil, acting as source of income for a large amount of small producers and aiding in their settlement in the rural area. The easy proliferation, the lower nutritional requirement of the goats and the facility to adapt to the semiarid * changes in the consumer market that caused an increase on the demand for the processed viscera have been observed, what furthered the use of edible components not belonging to the goat carcass in the production of sausages or prepared

\footnotetext{
* Author for correspondence
}

environmental conditions are factors that contribute to make this activity relevant. The goat flock in the region is represented by an effective of almost nine million heads, corresponding to $93.4 \%$ of the overall national goat flock (IBGE, 2003).

The goat breeding for slaughter stands out with the production of high nutritional quality meat and especially for being an exchange value-generating product. However, in the past years, significant dishes, considered as a promising activity based on a full-expansion market stimulated by large supermarket nets, restaurants and hotels (Carvalho, 2003).

Galstaldi et al. (2001) reported that the importance of the use of edible components not belonging to 
goat carcass of small size ruminants was not only associated to the economic profit but also to the lost food or raw material, which could contribute to decrease the prices of final products and to improve the quality of life of the less favored populations.

Costa et al. (2003) reported that the use of goat organs and viscera in the elaboration of typical dishes from the local cookery, for example the goat buchada, represent an excellent and feasible economic alternative, adding value and increasing the production profitability. Generally, the buchada is composed of heart, lungs, liver, spleen, intestines, stomach and blood. Costa et al. (2005) studied the yield of goat viscera and observed that the goat buchada represented an additional budget of $57.51 \%$ in relation to the carcass value.

The quantification of the edible components that composed the goat buchada would reveal the information on the product output, allowing the establishment of cost-benefit relations in the production and commercialization stages. The characterization of the product's nutritional value, considering the lack of data in literature, could promote a higher acceptance, and hence, a significant growth on the demand. The objective of the present work was to collect such information by quantifying the ingredients and determining the composition chemistry of the precooked goat buchada produced in the state of Paraíba.

\section{MATERIALS AND METHODS}

The experiment was conducted using the precooked goat buchadas acquired in informal slaughterhouses from the cities of Campina Grande, Remígio, São João do Cariri, Barra de Santa Rosa and Patos, including the Agreste, Borborema and Sertão mesoregions in the state of Paraíba, Brazil. Four sequenced collections were performed within a period of seven consecutive days, collecting the samples from the five cities previously mentioned. Later, the physicochemical determinations were performed and this procedure was analogically performed for the other samples. All product processing stages were followed, in other words, cleanness, thermal treatment of viscera and confection of the buchada, proceeding with the addition from condiments and vegetables and posterior wadding of the rumen (with the perforated) and closing for subsequent baking. All the ingredients were quantified.

The weighting of the components was performed in analogical scale at the collection site shortly after scalding before cutting for the mincing. The samples were collected shortly after the final product. For transportation, the samples were packed in transparent plastic sacks with hermetic seal, previously sterilized with iodinated alcohol and registered in informative cards containing date and site of collection. The samples were transported in isothermal boxes with ice to the food analysis laboratory and frozen in freezer under average temperature of $-18^{\circ} \mathrm{C}$ for a period shorter than fourteen days.

The compositional chemistry determinations were performed at the Food Analysis Laboratory of the Technology Center - Paraíba Federal University, João Pessoa.

For the performance of the physicochemical evaluation of the goat buchada, the samples were ground in blender for a period of 20 minutes until complete homogenization of the material. The humidity, ashes and protein determinations were performed according to the AOAC (1975). The total lipid contents were determined through the method of Folch et al. (1956).

The design used was fully random with five treatments and represented by the product acquired in each city (Campina Grande; Patos; Remígio; Barra de Santa Rosa; São João do Cariri). The four collections performed for each treatment were characterized as repetitions of the experiment. The averages were compared with the Tukey test at the significance level of $5 \%$ of probability using the PROC GML from the SAS program as software (SAS, 1996).

\section{RESULTS AND DISCUSSION}

In the evaluation of the goat buchada components, it was observed that the blood, high nutritional value and important component, was not used in the product formation acquired in Campina Grande [Fig. 1 (a)] and that the spleen was not used in the formulation of the goat buchada acquired in Patos [Fig. 1 (b)].

A higher yield for the goat buchada acquired in Remígio was observed due to the high percentage of intestines, blood, greenstuffs and fat (omental 
and mesenteric) in the product (Table 1). Costa et al. (2003) reported higher goat buchada yield, between 18.73 and $18.82 \%$, and the compounds which accounted for these values were omental and mesenteric fat and intestines and blood obtained from the slaughtered animal, thus providing higher buchada yielding. However, the goat buchadas produced in the stores visited, only part of these components were used and, therefore, a lower yield was observed when compared to data presented in the literature.

It was also observed that the products obtained in Patos, Barra de Santa Rosa and São João do Cariri presented buchada yield of 5.35 and $6.85 \%$ as result of the low utilization of the edible components not belonging to the carcass in the formation of the product.

The products analyzed presented humidity values (Table 2) equivalent to values mentioned by Anderson (1988) for in natura sheeplike organs and by Madruga et al. (2003) for in natura goatlike viscera. Nascimento et al. (2000) observed that the precooked goat buchada produced in the Cariri region presented $66 \%$ of humidity.

A large variation in the ashes content in the samples was observed and this variation was corroborated by the high variation coefficient reported. Lower ash content values were reported by Nascimento et al. (2000) in goat buchada samples and by Madruga et al. (2003) in goat viscera.

A high protein content was observed in the products analyzed; however, these values were lower than those presented by Nascimento et al. (2000), $18.33 \%$ of proteins in the goat buchada.
Madruga et al. (2003) reported a wide variation in the protein content in in natura goatlike organs such as heart, lung, liver and stomach, between 14.55 and $20.26 \% ; 15.83$ and $16.94 \% ; 19.46$ and $27.75 \%$ and 15.27 and $16.87 \%$, respectively, and the lowest content of around $12.48 \%$ was reported for intestine samples. Anderson (1988) analyzed the protein content in sheeplike organs and observed values of $14.83,20.99,16.70,17.20$, 15.75 and $12.90 \%$ for heart, lung, spleen, tongue and intestines, respectively

A high variation in the lipid content was observed $(\mathrm{CV}=41.72 \%)$ possibly as result of the lack of standardization in relation to the products produced in the state and no control on the parameters such as age, weight and breed of the slaughtered animals was found. Although no statistical difference was observed in the lipid contents, the highest values were observed in the samples from the cities of Remígio and Barra de Santa Rosa (14.52 and $15.90 \%$, respectively). Such values were a result of the addition of high amounts of omental and mesenteric fat in the goat buchada (8.90 and $10.42 \%$, respectively) and probably one the slaughter of older animals, consequently with higher amounts of visceral fat.

Anderson (1988) reported lower lipid values for in natura sheeplike organs: heart with $5.69 \%$, liver with $4.61 \%$, lung with $2.60 \%$ and spleen with $3.10 \%$; however, tongue fat content above $17 \%$. Nascimento et al. (2000) reported lipid content of 9.58\% for the precooked goat buchada (dry matter basis). Madruga et al. (2003) found higher lipid content for the goat heart and liver (13.29 and $10.32 \%$, respectively) and values below $1.28 \%$ in stomach and intestine samples. 


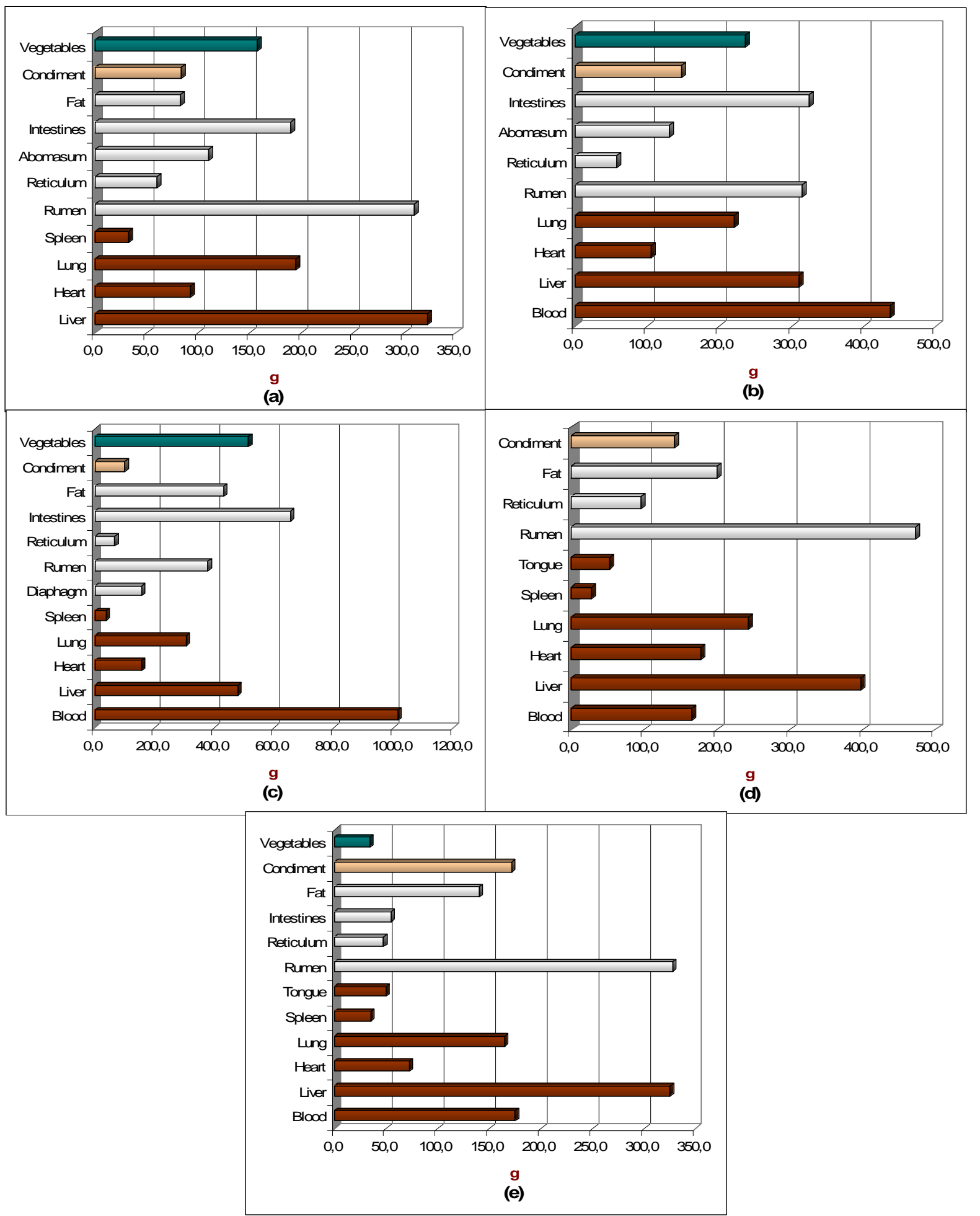

Figure 1 - Weight (g) of the edible components not belonging to carcass, seasonings and greenstuffs in the goat buchada collected in Campina Grande (a), Patos (b), Remígio (c), Barra de Santa Rosa (d) and São João do Cariri (e). 
Table 1 - Percentage of the non-constituent eatable components of the carcass of buchada.

\begin{tabular}{|c|c|c|c|c|c|c|}
\hline \multirow{2}{*}{ Constituent (\%) } & \multicolumn{5}{|c|}{ City } & \multirow{2}{*}{ CV $(\%)$} \\
\hline & C. Grande & Patos & Remígio & B.S. Rosa & S.J. Cariri & \\
\hline Condiment & $5.16^{\mathrm{c}}$ & $6.39^{b}$ & $2.30^{\mathrm{d}}$ & $7.00^{\mathrm{b}}$ & $11.08^{\mathrm{a}}$ & 8.18 \\
\hline Vegetables & $9.67^{\mathrm{a}}$ & $10.25^{\mathrm{a}}$ & $11.78^{\mathrm{a}}$ & - & $2.20^{\mathrm{b}}$ & 13.88 \\
\hline Fat & 5.24 & - & 8.90 & 10.42 & 8.32 & 48.04 \\
\hline Blood & - & $18.03^{\mathrm{ab}}$ & $23.72^{\mathrm{a}}$ & $8.94^{\mathrm{b}}$ & $11.39^{\mathrm{b}}$ & 32.06 \\
\hline Liver & $19.87^{\mathrm{a}}$ & $13.82^{\mathrm{b}}$ & $11.20^{\mathrm{b}}$ & $20.83^{\mathrm{a}}$ & $21.82^{\mathrm{a}}$ & 14.13 \\
\hline Heart & 5.79 & 5.77 & 3.68 & 7.72 & 4.79 & 41.87 \\
\hline Lung & 11.93 & 10.03 & 7.18 & 13.14 & 10.81 & 32.99 \\
\hline Spleen & $2.01^{\mathrm{ab}}$ & - & $0.91^{\mathrm{b}}$ & $1.68^{\mathrm{ab}}$ & $2.23^{\mathrm{a}}$ & 34.58 \\
\hline Rumen & $18.53^{\mathrm{ab}}$ & $12.74^{\mathrm{bc}}$ & $8.82^{c}$ & $23.01^{\mathrm{a}}$ & $21.43^{\mathrm{a}}$ & 21.65 \\
\hline Reticulum & $3.67^{\mathrm{a}}$ & $3.02^{\mathrm{ab}}$ & $1.57^{\mathrm{b}}$ & $4.66^{\mathrm{a}}$ & $3.18^{\mathrm{ab}}$ & 26.14 \\
\hline Abomasum & 6.65 & 7,52 & - & - & - & 54.06 \\
\hline Diaphagm & - & - & 4.64 & - & - & 38.99 \\
\hline Intestines & $11.48^{\mathrm{b}}$ & $14.32^{\mathrm{ab}}$ & $15.30^{\mathrm{a}}$ & - & $3.59^{c}$ & 14.29 \\
\hline Tongue & - & - & - & 2.61 & 3.32 & 19.81 \\
\hline Weight of the buchada $(\mathrm{kg})$ & $1.40^{\mathrm{b}}$ & $1.88^{\mathrm{b}}$ & $3.74^{\mathrm{a}}$ & $1.86^{\mathrm{b}}$ & $1.33^{\mathrm{b}}$ & 38.90 \\
\hline Body weight $(\mathrm{kg})$ & 17.50 & 26.75 & 31.38 & 33.25 & 20.00 & 42.60 \\
\hline Income of the buchada $(\%)$ & $8.00^{\mathrm{b}}$ & $6.85^{\mathrm{bc}}$ & $12.41^{\mathrm{a}}$ & $5.35^{\mathrm{c}}$ & $6.75^{\mathrm{bc}}$ & 15.00 \\
\hline
\end{tabular}

Means with different letters within the same line differ among then by Tukey test $(\mathrm{P}<0.05)$

Table 2 - Composition chemistry (g/100g) of the precooked goatlike buchada

\begin{tabular}{lcccc}
\hline \multirow{2}{*}{ City } & \multicolumn{4}{c}{ Attribute $(\mathbf{g} / \mathbf{1 0 0 g})$} \\
\cline { 2 - 5 } & Water & Ashes & Protein & Fat \\
\hline C. Grande & 75.77 & 1.55 & $13.65^{\mathrm{ab}}$ & 7.22 \\
Patos & 71.34 & 3.13 & $14.43^{\mathrm{ab}}$ & 7.08 \\
Remígio & 69.42 & 2.15 & $12.11^{\mathrm{b}}$ & 14.52 \\
B.S. Rosa & 65.73 & 2.00 & $16.75^{\mathrm{a}}$ & 15.90 \\
S.J. Cariri & 73.53 & 2.30 & $14.87^{\mathrm{ab}}$ & 7.43 \\
\hline CV $(\%)$ & 6.89 & 34.64 & 11.42 & 41.72 \\
\hline
\end{tabular}

Means with different letters within the same column differ among then by Tukey test $(\mathrm{P}<0.05)$.

\section{CONCLUSION}

The goat buchada presented lower yield of the live weight of the animals than those observed in literature, showing that only part of the edible components not belonging to carcass was actually used in the formation of the product.

The goat buchada presented expressive protein values and lipid contents.

The lack of standardization in the concentration of edible components not belonging to carcass used in the formation of the goat buchada provided the products with large variation in the compositional chemistry, especially in the lipid content.

\section{RESUMO}

Objetivou-se com o presente trabalho, quantificar os constituintes e determinar a composição química da buchada caprina pré-cozida produzida no estado da Paraíba, Brasil. A buchada apresentou um considerável rendimento em relação ao peso vivo. Verificou-se um elevado teor protéico nos produtos analisados. O conteúdo lipídico apresentou alta variação, em decorrência da falta de padronização dos produtos confeccionados no estado, não havendo controle dos parâmetros de idade, peso, sexo e raça dos animais abatidos. Embora não se tenha observado diferença $(\mathrm{P}<0.05)$ no teor lipídico, os maiores percentuais foram constatados nas amostras provenientes de Remígio e Barra de Santa Rosa, 
com 14.52 e $15.90 \%$, respectivamente, decorrente da adição de grandes quantidades de gordura omental e mesentérica na buchada e provavelmente do abate de animais com idade mais avançada.

\section{REFERENCES}

Anderson, B. A. E. (1988), Composition and nutritional value of edible meat by-products. In: Edible meat byproducts. A. M. Pearson and T. R. Dutson, Cap. 1, London: Elsevier, pp. 15-45.

Association of Official Analytical Chemists - AOAC. (1975), Official methods of analysis. D. C. Washington, 12, 1094.

Carvalho, R. B. (2003) Potencialidades dos mercados para os produtos derivados de caprinos e ovinos. http://www.capritec.com.br.

Costa, R. G.; Madruga, M. S.; Santos, N. M.; Medeiros, A. N. (2005), Qualidade físico-química, química e microbiológica da "buchada" caprina. Revista Higiene Alimentar, 19(130), 62-68.

Costa, R. G.; Medeiros, A. N.; Madruga, M. S. et al. (2003), Rendimento de vísceras para "buchada" em caprinos Saanen alimentados com diferentes níveis de volumoso e concentrado. In-Simpósio Internacional Sobre Caprinos e Ovinos de Corte, 2., João Pessoa, Brasil.

Honório, A. F. (2003), Utilização do farelo de girassol em rações completas para borregos da raça Santa Inês nos fases de recria e terminação. Monografia (Graduação em Zootecnia), Centro de Ciências Agrárias/ Universidade Federal da Paraíba, Areia, Paraíba, Brasil. pp. 22-23.
Gastaldi, K. A.; Silva Sobrinho, A. G.; Machado, M. R. F. et al. (2001), Proporção dos componentes não constituintes da carcaça em cordeiros alimentados com dietas com diferentes relações volumoso concentrado e abatidos aos 30 ou $31 \mathrm{~kg}$ de peso vivo. In: $38^{\text {th }}$ Reunião Anual da Sociedade Brasileira de Zootecnia, Piracicaba, pp. 956-957.

Folch, J.; Less, M.; Stanley, G.H.S. (1957), A simple method for the isolation and purification of lipids from animal tissues. Journal Biology and Chemistry, 226, 497-509.

Madruga, M. S.; Rezer, J. S.; Pedrosa, N. A. et al. (2003), Caracterização química e microbiológica de vísceras caprinas destinadas ao preparo de buchada e picado. Revista Nacional da Carne, 27(316), 37-45.

Nascimento, J. C.; Souza, S.; Fernandes, J. D. C. et al. (2000), Aproveitamento Tecnológico e Condições de Qualidade no Processamento de Buchada Caprina Pré-Cozida na Região do Cariri do Estado da Paraíba. In: $17^{\text {th }}$ Congresso Brasileiro de Ciência e Tecnologia de Alimentos, 3, 11-62.

SAS Institute. (1996), Statistic Analyses Systems (User's guide: statistics).Version 6.0, Cary, 4, 300.

Received: September 19, 2005; Revised: January 17, 2007; Accepted: March 29, 2008. 